\title{
Improving of Mathematics Understanding Through Interactive Powerpoint Media of Third Grade Students.
}

\section{Diah Retno Wati}

SD Negeri Tegowanuh

diahnonee@gmail.com

\section{Article History}

accepted 01/11/2020

published 15/11/2020

\begin{abstract}
The purpose of this study was to improve students' understanding of mathematics learning in grade III SD. This research is a Classroom Action Research which is conducted in 3 cycles. Each cycle consists of stages of planning, implementing, observing and reflecting. The subjects of this study were students of class III SDN Tegowanuh in the academic year 2020/2021, totaling 30 students. Data collection techniques using observation and tests. Data analysis includes data reduction, data presentation, and drawing conclusions. Research shows that the use of interactive powerpoint media can improve understanding of the third grade students' time conversion in the 2020/2021 academic year as evidenced by the percentage of completeness of learning outcomes and the class average. In the first cycle it was $50 \%$ with a class average of 80.3 to $100 \%$ with a class average of 89.8 in the second cycle and $100 \%$ with a class average of 94 in the third cycle.
\end{abstract}

Keywords: Mathematics ,Interactive Powerpoint, Understanding

\begin{abstract}
Abstrak
Tujuan Penelitian ini adalah untuk meningkatkan pemahaman peserta didik pada pembelajaran matematika kelas III SD. Penelitian ini merupakan Penelitian Tindakan Kelas yang dilaksanakan dalam 3 siklus. Setiap siklus terdiri dari tahapan perencanaan, pelaksanaan, observasi dan refleksi. Subjek penelitian ini adalah peserta didik kelas III SDN Tegowanuh Tahun Pelajaran 2020/2021 yang berjumlah 30 peserta didik. Teknik pengumpulan data menggunakan observasi dan tes. Analisis data meliputi reduksi data, penyajian data, dan penarikan kesimpulan. Penelitian menunjukkan bahwa penggunaan media powerpoint interaktif dapat meningkatkan pemahaman konversi waktu siswa kelas III tahun pelajaran 2020/2021 yang dibuktikan dengan persentase ketuntasan hasil belajar dan rata-rata kelas. Pada siklus I sebesar $50 \%$ dengan rata-rata kelas 80,3 menjadi $100 \%$ dengan rata-rata kelas 89,8 pada siklus II dan $100 \%$ dengan rata-rata kelas 94 pada siklus III.
\end{abstract}

Kata kunci: Matematika, Powerpoint Interaktif, Pemahaman.

Social, Humanities, and Education Studies (SHEs): Conference Series https://jurnal.uns.ac.id/shes

p-ISSN 2620-9284

e-ISSN 2620-9292 


\section{PENDAHULUAN}

Matematika sebagai salah satu mata pelajaran di sekolah dinilai sangat memegang peranan penting karena matematika dapat meningkatkan pengetahuan peserta didik dalam berpikir secara logis, rasional, kritis, cermat, efektif, dan efisien. Oleh karena itu, pengetahuan matematika harus dikuasai sedini mungkin oleh para peserta didik. Menurut Ruseffendi dalam Heruman (2007: 1) matematika adalah bahasa simbol; ilmu deduktif yang tidak menerima pembuktian secara induktif; ilmu tentang keteraturan, dan struktur yang teroganisasi, mulai dari unsur yang tidak didefinisikan, ke unsur yang didefinisikan, ke aksioma atau postulat, dan akhirnya kedalil. Menurut piaget, mereka berada pada frase operasional konkret. Kemampuan yang tampak pada frase ini adalah kemampuan dalam proses berfikir untuk mengoperasikan kaidah-kaidah logika, meskipun masih terkait dengan objek yang bersifat konkret (Heruman, 2007: 1).

Mata pelajaran ini yang memegang peranan penting dalam membentuk siswa yang berkualitas. Matematika merupakan salah satu sarana untuk berfikir untuk mengkaji sesuatu yang sangat logis dan sistematis maka perlu adanya peningkatan mutu pembelajaran dan salah satu usaha harus dilakukan adalah memperbaiki kualitas pembelajaran matematika sehingga belajar matematika peserta didik dapat ditingkatkan. Faktanya pembelajaran matematika di SD penggunaan metode dan media belum maksimal, seringnya guru menjadi satu-satunya sumber belajar peserta didik.

Berdasarkan hasil pengamatan yang telah dilakukan di kelas III SDN Tegowanuh, materi konversi waktu pada pelajaran matematika sulit di pahami oleh peserta didik. Peserta didik sudah pahami mengenai jam dengan waktu yang tepat namun masih belum mahir bila ditanya tentang menitnya. Pada semester I hasil belajar yang diperoleh belum maksimal dari 30 anak sesuai standar KKM 70,00 hanya 15 atau $50 \%$ peserta didik. Penggunaan strategi pembelajaran yang digunakan guru sudah bagus, namun ada beberapa kekurangan seperti pembelajaran ini masih bernuansa teacher center dan penyampaian informasi yang bersifat satu arah sehingga kurang diberdayakan, peserta didik tidak dilibatkan secara aktif maka peserta didik susah dalam menyerap materi yang dipelajari. Media pembelajarannya juga hanya menggunakan media jam analog saja, sehingga menyebabkan kurangnya menarik perhatian dan minat dari peserta didik saat diajarkan materi satuan waktu. Hasil belajarpun masih rendah dan masih banyak yang mempunyai nilai dibawah KKM (Kriteria Ketuntasan Minimal).Berdasarkan hal tersebut, peneliti memandang perlu menerapkan media pembelajaran yang dapat meningkatkan hasil belajar peserta didik. Tindakan yang dilakukan yaitu penerapan media pembelajaran Powerpoint Interaktif. Menurut Suyanto (2015: 1) menyatakan bahwa, "Microsoft Office Power Point adalah aplikasi yang memungkinkan untuk dapat merancang dan membuat presentasi secara mudah, cepat, serta dengan tampilan yang menarik dan professional".Sedangkan Powerpoint Interaktif merupakan powerpoint yang bersifat interaktif yakni dalam pembuatannya ada 4 hal yang perlu diketahui agar multimedia yang dibuat lebih mudah dan hasil akhirnya powerful, yaitu: (1) slide master yang berfungsi untuk menambahkan hyperlink antar slide dengan rancangan tombel dan tema yang sama; (2) hyperlink yang berfungsi sebagai navigasi untuk berpindah slide; (3) annimation trigger yang berfungsi menjalankan animasi yang diawali dengan mengklik suatu objek yang dijadikan pemicunya; dan (4) Visual Basic for Application (VBA) yang merupakan bahasa pemrograman visual basic yang dikembangkan 
Microsoft Office, terutama untuk power point untuk menggantikan fungsi animasi dengan menuliskan sederet bahasa pemrograman

Berdasarkan data-data di atas, peneliti tertarik untuk melakukan penelitian dengan judul "Peningkatan Pemahaman Matematika Menentukan Konversi Waktu Melalui Penggunaan Media Pembelajaran PowerPoint Interaktif pada Peserta didik Kelas III Semester Ganjil SD Negeri Tegowanuh Tahun Pelajaran 2020/2021".

Benjamin S. Bloom dalam Anas Sudjiono (2009, h. 50) mengatakan bahwa pemahaman (Comprehension) adalah kemampuan seseorang untuk mengerti atau memahami sesuatu setelah sesuatu itu diketahui dan diingat. Dengan kata lain, memahami adalah mengerti tentang sesuatu dan dapat melihatnya dari berbagai segi. Menurut Nana Sudjana, pemahaman adalah hasil belajar, misalnya peserta didik dapat menjelaskan dengan susunan kalimatnya sendiri atas apa yang dibacanya atau didengarnya, memberi contoh lain dari yang telah dicontohkan guru dan menggunakan petunjuk penerapan pada kasus lain. Disekolah hasil belajar biasanya dinilai dengan angka. Peserta didik akan mendapat nilai yang akan menggambarkan keberhasilan dalam belajar.

\section{METODE}

Penelitian ini adalah penelitian tindakan kelas (Classroom Action Research) dengan menerapkan media powerpoint interaktif. Menurut Kurt Lewin dalam Kunandar (2011: 42) penelitian tindakan kelas ini terdiri dari empat tahapan dasar yaitu perencanaan (planning), pelaksanaan (acting), pengamatan (observing) dan refleksi (reflecting). Analisis penelitian ini adalah analisis deskriptif kuantitafif kualitatif dimana dalam penelitian ini selain penyajian hasil berupa data maupun angka peneliti juga menentukan bagaimana cara pengolahan hasil penelitian yakni dengan membuat analisisnya dengan menerapkan media powerpoint interktif. Penelitian ini dilaksanakan pada peserta didik kelas III SD Negeri Tegowanuh Tahun Pelajaran 2020/2021 selama tiga siklus secara daring menggunakan aplikasi zoom meet .Siklus I dilaksanakan pada Kamis, 22 Oktober 2020 Siklus II dilaksanakan pada Senin, 2 November 2020 .Siklus III dilaksanakan pada Jumat , 13 November 2020. Teknik pengumpulan data yang dilakukan dengan observasi dan tes, baik pre test maupun post test. Observasi meliputi observasi keterlaksanaan media powerpoint interaktif, sikap peserta didik dan keterampilan. Untuk hasil belajar menggunakan tes melalui Google form.

\section{HASIL DAN PEMBAHASAN}

Berdasarkan analisis hasil penelitian yang telah diuraikan maka pembahasan pada penelitian ini sebagai berikut.

\section{Penggunaan Media Powerpoint Interaktif}

Hasil penelitian menunjukkan peningkatan pemahaman siswa melalui penggunaan media powerpoint interaktif. Terilhat pada tabel berikut:.

Tabel 1. Peningkatan Pemahaman Siswa Melalui Penggunaan Powerpoint Interkatif

\begin{tabular}{lccc}
\hline \multicolumn{1}{c}{ Aspek } & \multicolumn{3}{c}{ Siklus } \\
\hline $\begin{array}{l}\text { Pemahaman kalimat/materi } \\
\text { yang ditampilkan. }\end{array}$ & 3 & 3 & 4 \\
$\begin{array}{l}\text { Ketertarikan pada } \\
\text { background gambar . }\end{array}$ & 3 & 4 & 4
\end{tabular}


SHEs: Conference Series 3 (3) (2020) $422-427$

Ketertarikan penerapan

animasi pada media

Kesesuaian Konten materi

dengan yang dipelajari

Pengembangan untuk

berpikir kritis
3

3

3
3

4

3
4

4

4

Dari data observasi yang diperoleh pada tabel di atas menunjukkan bahwa aktivitas mengajar atau kegiatan mengajar guru (peneliti) mengalami peningkatan dari siklus I ke siklus II hingga Siklus III.

\section{Hasil Belajar pada pelajaran Matematika materi Konversi Waktu}

Hasil penelitian menunjukkan peningkatan hasil belajar pada pelajaran matematika materi Konversi Waktu. Terlihat pada grafik berikut:
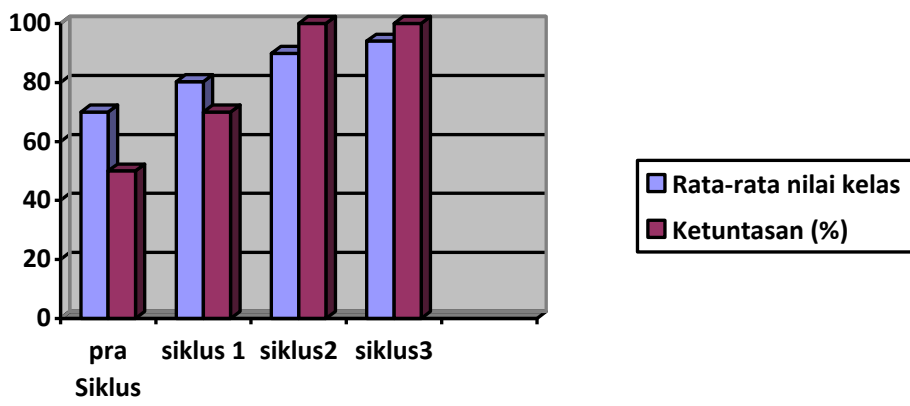

\section{Grafik 1. Hasil Belajar per Siklus}

Berdasarkan grafik di atas terlihat bahwa pada prasiklus sebelum penggunaan Powerpoint dilaksanakan. Pada akhir pembelajaran, setelah guru mengadakan tes formatif ternyata nilai yang diperoleh siswa belum sesuai dari yang diharapkan. Peneliti bersama teman sejawat mencari permasalahan tersebut. Kesimpulannya siswa belum dapat memahami serta menguasai materi Konversi Waktu pelajaran Matematika. Hal ini dapat dilihat dari hasil nilai formatif. Dari sejumlah 30 siswa pada prasiklus yang memperoleh nilai sesuai standar KKM 70,00 ketuntasan belajar ada 15 peserta didik atau $50 \%$. Melihat hal tersebut maka perlu adanya perbaikan pembelajaran ke siklus I dengan penerapan media pembelajaran powerpoint.Untuk memperbaiki dan meningkatkan prestasi belajar siswa, maka pada siklus I guru berupaya meningkatkan pemahaman belajar materi Konversi Waktu pada pelajaran matematika. Selain itu guru berupaya maksimal untuk menciptakan suasana belajar di kelas lebih aktif, kreatif, dan menyenangkan untuk membuat siswa lebih aktif dalam mengikuti proses pembelajaran.Siswa termotivasi untuk belajar.

Dari hasil pengamatan oleh teman sejawat pada perbaikan siklus I dari sejumlah 30 peserta didik banyak yang mengalami peningkatan nilai tes formatifnya. Pada siklus 1 ,peserta didik yang telah mencapai KKM KD 70 ada 21 anak (70\%), sedangkan 9 peserta didik lainnya (30 \%) belum berhasil mencapai KKM yang ditentukan . Hal ini menunjukkan bahwa proses pembelajaran yang peneliti lakukan sudah ada peningkatan $20 \%$ dari kondisi awal yakni dari $50 \%$ menjadi $70 \%$, namun belum mencapai indikator kinerja sehingga perlu dilanjutkan ke siklus 2 . Setelah direnungkan dalam tahap refleksi oleh guru maupun pengamat, faktor-faktor yang mempengaruhi kekurang berhasilan peserta didik antara lain: Penggunaan media Powerpoint Interaktif belum optimal, sehingga peserta didik masih sulit 
memahami materi dan peserta didik masih kurang berani bertanyan kepada guru apabila menemukan kesulitan dalam memahami materi Konversi Waktu pelajaran Matematika. Menindaklanjuti dari hal tersebut maka peneliti perlu mengadakan perbaikan pembelajaran siklus II untuk meningkatkan pemahaman peserta didik pada materi Konversi waktu dengan mengoptimalkan penggunaan media powerpoint interaktif.

Pada siklus II penggunaan media powerpoint interaktif dilaksanakan secara optimal oleh guru. Pada akhir pembelajaran, setelah peneliti mengadakan tes formatif ternyata nilai yang diperoleh siswa sesuai yang diharapkan. Hal ini dapat dilihat dari hasil nilai formatif. Dari sejumlah 30 peserta didik yang mencapai ketuntasan belajar sejumlah 30 atau $100 \%$ dengan rata-rata kelas 90.03 . Hal ini menunjukkan bahwa proses pembelajaran yang peneliti lakukan sudah ada peningkatan $30 \%$ dari kondisi siklus I ke siklus II yakni dari $70 \%$ menjadi $100 \%$.

Proses pembelajaran siklus II sudah menunjukkan adanya peningkatan. Hal ini dapat dilihat dari meningkatnya nilai rata-rata tes formatif dari siklus I yaitu 80,3 menjadi 89,8 di siklus II. Dengan ini dapat dilihat bahwa peningkatan dari hasil ratarata nilai kelas siklus I ke siklus II yakni sebesar 9.6. Peningkatan hasil rata-rata ini dikarenakan guru dalam proses pembelajaran lebih optimal dengan menggunakan media powerpoint interaktif. Untuk lebih memantapkan hasil dan meningkatkan ratarata nilai kelas penulis ingin melanjutkan kesiklus ke III.

Pada siklus III penggunaan media powerpoint interaktif dioptimalkan oleh guru. Pada akhir pembelajaran, setelah peneliti mengadakan tes formatif ternyata nilai yang diperoleh siswa sesuai yang diharapkan. Hal ini dapat dilihat dari hasil nilai formatif. Dari sejumlah 30 peserta didik yang mencapai ketuntasan belajar sejumlah 30 atau $100 \%$ dengan rata-rata kelas 94 . Proses pembelajaran siklus III menunjukkan adanya peningkatan. Hal ini dapat dilihat dari meningkatnya nilai ratarata kelas dari siklus II yaitu 89,8 menjadi 94 di siklus III. Jadi dari siklus II ke siklus III terdapat peningkatan hasil rata- rata nilai kelas sebesar 4.2 Peningkatan hasil rata-rata ini dikarenakan guru dalam proses pembelajaran lebih optimal dengan menggunakan media powerpoint interaktif.

Berdasarkan penjelasan yang sudah yang sudah diuraikan diatas, maka peneliti tidak melanjutkan perbaikan, karena kemampuan pemahaman siswa pada materi konversi waktu pelajaran Matematika yang dicapai siklus III telah mengalami peningkatan yang signifikan. Siswa yang telah mencapai ketuntasan belajar pada belajar mencapai $100 \%$. Hasil pengamatan teman sejawat, terlihat bahwa setelah menjelaskan materi konversi waktu melalui penggunaan media powerpoint interaktif, kemampuan pemahaman siswa pada materi konversi waktu pelajaran matematika meningkat siklus III berjumlah 30 orang atau 100\% dengan rata-rata kelas 94 . Prosentase ketuntasan, dibuktikan dengan hasil perolehan nilai yang dicapai oleh siswa dalam tes siklus III meningkat.

\section{SIMPULAN}

Penggunaan Media Powerpoint Interaktif pada Pembelajaran Siswa Kelas III Semester Ganjil SD Negeri Tegowanuh Tahun Pelajaran 2020/2021. Dapat diambil kesimpulan sebagai

berikut:

(1) Dalam penelitian tindakan kelas ini peneliti meneliti tentang pemahaman siswa pada pelajaran Matematika

(2) Hasil belajar siswa sebelum menggunakan Media powerpoint Interaktif pada 
SHEs: Conference Series 3 (3) (2020) $422-427$

pelajaran matematika materi Konversi Waktu memiliki hasil belajar dengan ketuntasan 50\%. Dalam hal ini hasil belajar peserta didik masih di bawah indikator keberhasilan dan ingin dilakukan perubahan.

(3) Berdasarkan hasil penelitian pada siklus I, siklus II, dan siklus III setelah diterapkannya Model Pembelajaran dengan menggunakan Media powerpoint interkatif dapat meningkatkan pemahaman peserta didik pada pelajaran matematika materi konversi waktu. Hal ini dapat dibuktikan dengan hasil belajar peserta didik yang meningkat setelah diterapkannya Model Pembelajaran menggunakan Media powerpoint interaktif. Pada tahap Pra Siklus ketuntasan kelas hanya $50 \%$. Pada Siklus I rata-rata nilai kelas 80,3 dengan ketuntasan $70 \%$. Pada Siklus II rata-rata nilai kelas 89.8 dengan ketuntasan mencapai 100\%. Dan pada siklus III Tuntas 100\% dengan kenaikan rata-rata nilai kelas menjadi 94.

\section{DAFTAR PUSTAKA}

Anas Sudjiono. 2009. Pemahaman (comprehension) hal. 50

Kurt Lewin dalam Kunandar 2011. penelitian tindakan kelas Pengembangan Profesi Guru.Jakarta:Rajawali Pres.hal 42

Ruseffendi dalam Heruman (2007: 1) Model Pembelajaran Matematika.Bandung: PT REMAJA ROSDAKARYA. hal. 1

Sudjana, Nana. 2009. Penilain Hasil Proses Belajar Mengajar. Bandung: Remaja Rosdakarya

Suyanto, A.H 2015. Microsoft Office Power Point.Tangerang :pelatihan dan implementasi. hal.1https://ejournal.unesa.ac.id/index.php/jurnal-pendidikankewarganegaraa/article/view/18206/16594.Pengembangan

powerpoint interaktif.(diakses tanggal 21/10/2020 pukul 11.35) 